Religion and Gender, vol. 2, no. 2 (2012), pp.

280-304

www.religionandgender.org

URN:NBN:NL:UI:10-1-101603

ISSN: $1878-5417$

Publisher: Igitur Publishing (Utrecht)

Copyright: this work is licensed under a Creative

Commons Attribution License (3.0)

\title{
Reading Images of Christ: Masculinity and Homosexuality as Sites of Struggle in Popular Religious Images of Jesus
}

\author{
JUDITH SAMSON
}

\begin{abstract}
The attitude towards homosexuality has become one of the key markers of political identity. In Europe as well as in Northern America it has been used by different groups to promote their views. Especially between fundamentalist Christians and politically as well as religiously liberal people it has become a significant topic of contestation. This article argues that this struggle not only takes place on a textual, but also on a visual discursive level, in which the image of the Sacred Heart of Jesus is central. An analysis of the representation of Jesus' masculinity in this image shows that different groups, Polish fundamentalists at a pilgrimage site and liberal American producers of a satiric website, use different versions of the same image to either counter or support public acceptance of homosexuality.
\end{abstract}

\section{Keywords}

Sacred Heart of Jesus, popular religious art, divine mercy, Radio Maryja, homosexuality, masculinity 


\section{Author affiliation}

Judith Samson recently obtained her PhD from Radboud University Nijmegen (Netherlands): 'Sexuality and Gender Discourses at European Pilgrimage Sites' (2012). She has published professional articles on pilgrimages to the Black Madonna of Częstochowa and a scholarly article, "The Gender Agenda": New Strategies in Catholic Fundamentalist Framing of Non-Heterosexuality in Europe' in Journal of Religion in Europe 4:2 (2011), 1-27. Email: jusa2009@yahoo.com

\section{Introduction}

'Dedicating the Month of June: Sacred Heart of Jesus or the "LGBT" Agenda?'. This was the headline of an article by Deacon Keith Fournier in the online journal, American Catholic, in June 2010. The article criticized President Obama for declaring June 'the LGBT pride month', thus supposedly putting it in competition with June as the Catholic month of the Sacred Heart of Jesus. This rhetorical opposition between liberal sexual rights and Christian conservatism is not new. However, it is interesting that, in this case, the Sacred Heart devotion was chosen to counter LGBT (Lesbian Gay Bisexual Transgender) rights, because, paradoxically, this very image has received a lot of attention as it seems to present an androgynous Jesus whose heterosexual male identity is questionable. Especially on satirical websites criticizing fundamentalist religions, androgynous representations of Jesus have been used to question Jesus' masculinity and sexuality. At the same time, some fundamentalist Catholic groups have recently promoted 'manlier' images of the Sacred Heart of Jesus.

Popular religious representations have been contested from the moment of their production. Among the various issues about which they sparked discussion are gender roles and sexuality. The Catholic Church is currently struggling with homosexuality both inside and outside its own power structures. As David Morgan points out, the popular religious images of Christ have been produced and interpreted differently according to their social and historical context. ${ }^{1}$ As the struggle over homosexuality is one of the central issues within contemporary Christianity, the religious images produced by groups either opposing or supporting LGBT rights can be expected to react to this struggle.

Moreover, popular religious images have been shown not only to enhance 'prayer and devotional experience by focusing thought and

1 D. Morgan, Visual Piety: A History and Theory of Popular Religious Images, Berkeley: University of California Press 1998. 
petitions $^{2}$ and to sustain family relations ${ }^{3}$, but also to support sociopolitical movements. Thus, in the Catholic anti-abortion movement the images of the Virgin of Guadalupe and the Mother of the Unborn have gained trans-national significance in mobilizing people against the legality of abortion. ${ }^{4}$

Furthermore, critical modern religious art like Alma Lopez's version of Our Lady as a modern lesbian Chicana has been employed to further the emancipation of women and ethnic minorities. ${ }^{5}$ And the queer Jesus is currently part of a 'global revelation', ${ }^{6}$ so that he comes 'at a time when Christian rhetoric is used as an anti-gay weapon ... the queer Christ images have come to teach, heal and free anyone who accepts the challenge. ${ }^{7}$ Popular religious art is received so well because it can be interpreted in multiple ways and, therefore, reify those views of which people are already convinced. ${ }^{8}$

I aim to analyse how the struggle over recognition of sexual minorities is reflected in the current uses of popular religious images of Jesus. To do so, I will analyse how satirical websites supporting LGBT rights employ those images as well as which representations of Jesus are promoted by those Christians opposing LGBT rights. While the websites are American, the use of the images in pilgrimage rituals has been studied at the sacred site of the Black Madonna of Częstochowa in Poland. In both cases I will focus on one image: the popular representation of the Sacred Heart. This representation has been extensively involved in theoretical and theological discussions on (Christ's) masculinity and is amongst the most popular images used by the satirical websites and by fundamentalist groups like the Polish Radio Maryja. Further, the Sacred Heart image is similar to another very popular devotion, the 'Divine Mercy', which has not

2 Ibid., 157.

3 C. Notermans, 'Loss and Healing: a Marian pilgrimage in secular Dutch society', Ethnology 46:3 (2007), 217- 233.

4 L. Taylor, Occasions of Faith: An Anthropology of Irish Catholics, Philadelphia: University of Pennsylvania Press 1995, 246.; J. Samson, 'EU criticism in two anti-abortion movements at Marian pilgrimage sites' in W. Jansen and C. Notermans (ed.), Gender, Nation and Religion in European Pilgrimage, forthcoming.

5 A.-M. Korte, 'Madonna's kruisigingsscène: Blasfemie of theologische uitdaging?', Tijdschrift voor Theologie 49:2 (2009), 132-153, 147.

6 Y. Aburrow, 'Is it meaningful to speak of “Queer Spirituality?" An Examination of Queer and LGBT Imagery and Themes in Contemporary Paganism and Christianity', in S. Hunt (ed.) Contemporary Christianity and LGBT Sexualities, Farnham: Ashgate 2009, 150.

7 K. Cherry, Jesus in Love, Berkeley, CA: AndroGyne Press 1996, 13-14.

8 Morgan, Visual Piety, 122. 
been studied yet. Most importantly, I found that new versions of the Sacred Heart were recently launched that have not been analysed yet.

To study the use of the images by Christian fundamentalists, I will focus on two groups present at Marian pilgrimage sites, more specifically the pilgrimage site of the Black Madonna of Częstochowa in Poland. This site was chosen because it is among the most visited pilgrimage sites in Europe. Also Poland is a relatively new member state of the EU and was expected to play a specific role. Since the late 1990s, the Polish Church has actively supported Poland's integration into the EU. Encouraged by Pope John Paul II, it sees this integration also as a chance to strengthen Catholicism in the allegedly morally decayed Western European countries. ${ }^{9}$ At the same time Poland was pressured to adhere to the liberal paradigm of the EU. Thus, homosexuality has become a prominent topic of discussion with the entrance of Poland into the EU, also because potential members of the EU have been tested according to a 'gay scoreboard' on whether they could be admitted or not. ${ }^{10}$ Furthermore, the Black Madonna has become a repository of national identity in the course of Polish history. ${ }^{11}$ Thus discourses about the EU were expected to be reflected at this site. In addition, I encountered the different versions of the Sacred Heart image on flags, in chapels and in souvenir shops. As a Marian pilgrimage site the focus here is on Catholic fundamentalists.

However, the discourses on masculinity, and more specifically on homosexuality, are also current in other Christian traditions and therefore a comparison with American satirical websites that are aimed primarily at Evangelical fundamentalists seems legitimate. That means I acknowledge that there are differences in the theologies of Catholic and evangelical fundamentalism, but they share the core tenants of Christian faith and I focus here on a common feature, that is, their homophobia. Moreover, in Poland Catholicism is the predominant Christian denomination and in America it is evangelicalism. Both denominations are divided into different strands, but here only the fundamentalist part of both these movements comes into view. Furthermore, according to the European Baptist

9 A. Graff, 'Lost Between the Waves? The Paradoxes of Feminist Chronology and Activism in Contemporary Poland', Journal of International Women's Studies 2 (2003), 100-116, 110.

10 M. Graham, 'LGBT Rights in the European Union: A Queer Affair?', in E. Lewin and W. Leap (eds.), Out in Public: Reinventing Lesbian/Gay Anthropology in a Globalizing World, Malden: Wiley-Blackwell 2009, 304.

11 E. Matynia, 'Provincializing Feminism: The Polish Case', Social Research 61:2 (2003), 499-530; A. Niedzwiedz, The Image and the Figure: Our Lady of Częstochowa in Polish Culture and Popular Religion, Kraków: Jagiellonian Press 2010. 
Federation there are 'more than 800,000 Baptists in 51 unions stretching from Portugal to the far reaches of Russia.' ${ }^{12}$ Thus evangelicalism is not only an American phenomenon. As pilgrims told me, the pilgrimage site of the Black Madonna in particular has become the target of proselytizing evangelicals, and in the 1970s John Paul II had already invited the American evangelical Campus Crusade for Christ to fuse with the popular Polish spiritual renewal youth movement Oasis. ${ }^{13}$ According to CARA, an American non-profit research centre, about 66 million Americans are officially registered as Catholic. ${ }^{14}$ Many of those Catholics are descendants of Polish immigrants who still have families in Poland or visit the country as a tourist. Due to the turbo capitalism Poland has experienced in recent years, many people are faced with economic insecurities just like people in America. Also in both countries there has been an intertwining of politics with religion. However, while in America this intertwining has a long history, in Poland it is a rather new and heavily criticized phenomenon. Especially Radio Maryja that is under discussion here has received heavy criticism for mixing both. But also more liberal American Baptists in recent years have bemoaned the abuse of religion for political reasons ${ }^{15}$ and the satirists I study are among them.

Satirical websites have been chosen for several reasons. First, they often use the same images as the fundamentalists under discussion do. Secondly, they reach a large audience, both religious and secular. Thirdly, they employ the images in a directly political way to exercise criticism on fundamentalism, particularly homophobia, and are therefore different from queer art which has already been examined. ${ }^{16}$ Finally, as postmodern media they play with the notion of the fluidity of individual identity and with the notion of camp art, which is particularly significant in androgynous images of Jesus.

The focus will be on one particular satirical website, the Landover Baptist Church, which is representative of a great number of American websites dedicated to criticizing fundamentalist religion, especially evangelicalism, of which the Baptist Church is a part. Evangelicals form 35

12 www.ebf.org/about-ebf/, accessed 1 September 2012.

13 D. Scott, The Pope We Never Knew: The Unknown Story of How John Paul II Ushered Campus Crusade into Catholic Poland, www.christianitytoday.com, posted 19th April 2005, accessed 1 September 2012.

${ }^{14}$ http://cara.georgetown.edu/AboutCARA/aboutCARA.html, accessed 1 September 2012.

15 J. Dudley, Broken Words: The Abuse of Science and Faith in American Politics, New York: Crown Publishers 2011.

16 Aburrow, Is it meaningful; Cherry, Jesus. 
per cent of the Americans and have a significant influence on party politics. ${ }^{17}$ While there are different strands within evangelicalism, many evangelicals accept the so-called big four as key to their faith: 'abortion is murder; homosexuality, sin; evolution nonsense; and environmentalism, a farce. $^{18}$

An American website has been selected because there are no comparable European websites, yet Europeans also consume and support American websites like these. It is one of the most popular and most sophisticated websites; it provides a great deal of (manipulated) religious imagery and is also exemplary for the criticism of capitalist consumerism of many websites. Furthermore, it is also an example of postmodern art, the technique of which is irony and parody and which replaced Christianity as the grand narrative of Western culture. ${ }^{19}$ Not much has been written yet on satiric websites, so the focus on websites serves also to enrich theory in this field.

The method I use is a historical and comparative analysis of the images found on the webpages and at the pilgrimage site. I will look the various relations between the sign, Jesus, and the signifier, the various representations, as well as at denotation, the literal meaning, and connotations, the meanings given according to cultural and historical context.

\section{Theoretical points of departure}

\section{Fundamentalism}

As Radio Maryja is a fundamentalist Catholic group central to this discussion and the satiric websites I discuss are directly aimed at the criticism of fundamentalist groups, I want to begin by clarifying the use of the contested term 'fundamentalism'. Sociologists have focused on the social identity function of fundamentalist beliefs, ${ }^{20}$ while psychologists

17 Dudley, Broken Words, 13 -14.

18 Dudley, Broken Words, 11.

19 M. Danesi and P. Perron, Analyzing Culture:An Introduction \& Handbook, Bloomington: Indiana University Press 1999, 227.

${ }^{20}$ F. Ethridge, F. Maurice, R. Joe Feagin, 'Varieties of Fundamentalism: A Conceptual and Empirical Analysis of Two Protestant Denominations', Sociological Quarterly 20:1 (1979), 37-48; R.W. Hood, R.J. Morris, and P. Watson, 'Maintenance of religious fundamentalism', Psychological Reports 59 (1986), 547-559; P. Herriot, Religious Fundamentalism and Social Identity, London and New York: Routledge 2007. 
have described it as a mindset, ${ }^{21}$ a closed belief system ${ }^{22}$ or right-wing authoritarianism. ${ }^{23}$ The theologian Thomas O'Meara adds that what sets Catholic fundamentalism apart from other religious fundamentalisms is that it is unique in being a liturgical as well as a political fundamentalism, since most representatives oppose the liturgical renewal brought about by Vatican II along with a revolutionary reading of its documents. 'At the level of politics, Catholic fundamentalism becomes sectarian. It becomes hostile towards the cultures and governments of people. ${ }^{24}$ This can be specifically observed in Radio Maryja's hostility towards the EU and its support of the Tridentine rite. ${ }^{25}$

The same phenomenon has been labelled orthodox, traditionalist or conservative by different scholars. Because of this and the use of the term in a pejorative way in mainstream society, the term has been contested by some religious studies scholars. Nevertheless, I think that for this discussion the term is useful, as the social actors analysed here conform to what various scholars have described as fundamentalism. I adopt Malise Ruthven's definition of fundamentalism as a 'religious way of being' that manifests itself as a strategy by which beleaguered believers attempt to preserve their distinctive identity as a people or group in the face of modernity or secularization. ${ }^{26}$ Although the guardians of the Sacred Heart of Jesus, the other main group which introduced 'manlier' versions of the image, are registered on a web forum of traditionalist Catholics, ${ }^{27}$ they fit the latter description of fundamentalism by stressing their Catholic identity with the adoration of relics, the sacrament of confession and praying the rosary.

Furthermore, several scholars have pointed to the close relationship between religious fundamentalisms and both gender and sexuality issues. ${ }^{28}$

${ }^{21}$ F. Conway and J. Siegelman, Holy Terror, New York: Delta Books 1982.

22 M. Rokeach, The Open and Closed Mind, New York: Basic Books 1960; L. Kirkpatrick, R. Hood, and G. Hartz, 'Fundamentalist Religion Conceptualized in Terms of Rokeach's Theory of the Open and the Closed Mind: New perspectives on Some Old Ideas', Research in the Social Scientific Study of Religion 3 (1991), 157-179.

${ }^{23}$ R. Altemeyer, Right-wing Authoritarianism, Winnipeg: University of Manitoba Press 1981.

24 T.O'Meara, Fundamentalism: A Catholic Perspective, New York: Paulist Press 1990, 34.

${ }^{25}$ http://prawica.net/blog/26551, accessed 26 July 2012.

26 M. Ruthven, Fundamentalism: The Search for Meaning, Oxford: Oxford University Press 2004, 8.

27 https://traditia.fora.pl, accessed 15 July 2012.

28 J. Stratton Hawley (ed.), Fundamentalism and Gender, New York and Oxford: Oxford University Press 1994; J. Brink and J. Mencher (eds.), Mixed Blessings. Gender and Religious Fundamentalism Cross Culturally, New York and London: Routledge 1997; R. 
Willy Jansen observed that all kinds of fundamentalisms agree 'in the way they put a historically determined, urban middle class ideal of the family and gender relations on a divine level and grant it mythical proportions by presenting it as something eternal and divine. ${ }^{29}$ Gregory Herek has shown that there is a correlation between discriminatory attitudes towards lesbian and gay people and a fundamentalist attitude. ${ }^{30}$ Moreover, the issues of the ordinance of gay clergy and the acceptance of gay marriage have contributed to further internal division among Catholics, with the Vatican increasingly taking a right-wing position in these matters. Gene Burns argues that sexuality is one of the few issues left in which the Vatican tries to defend centralized church authority in the aftermath of Vatican II. ${ }^{31}$ While in the United States quite an amount of research has been done on how Christian fundamentalists frame their discourse on homosexuality, until now this is hardly the case for Europe. ${ }^{32}$

\section{Masculinity and Homosexuality}

Next I want to address the concepts of masculinity in general and homosexuality in particular. I follow Connell's observation that 'normative definitions of masculinity ... face the problem that not many men actually meet the normative standards. This point applies to hegemonic masculinity. ${ }^{33}$ I support the view of the constructiveness of masculinity that several scholars have pointed out. ${ }^{34}$ While Bourdieu has focused on

Feldman and K. Clark, 'Religious Fundamentalism and Reproductive Rights', Reproductive Health Matters 8 (1996); M. Riesebrodt, Pious Passion: The Emergence of Modern Fundamentalism in the United States and Iran, Berkeley: University of California Press 1993.

29 W. Jansen, Mythen van het fundament, Nijmegen: SUN 1993, 19.

30 G. Herek, 'Beyond "Homophobia": A Social Psychological Perspective on Attitudes Toward Lesbians and Gay Men', Journal of Homosexuality 10:1 (1984), 1-21.

31 G. Burns, 'Abandoning Suspicion: The Catholic Left and Sexuality', in M.J. Weaver (ed.), What's Left? Liberal American Catholics, Bloomington: Indiana University Press 1999, 69.

32 Ch. Robinson and S. Spivey, 'The Politics of Masculinity and the Ex-Gay Movement', Gender and Society 21 (2007), 650-675; M. Cuneo, The Smoke of Satan: Conservative and Traditionalist Dissent in Contemporary American Catholicism, Baltimore: The John Hopkins University Press 1999; Ruthven, Fundamentalism.

33 R.W. Connell, Masculinities, Oxford: Polity Press 1995, 79.

34 P. Bourdieu, Masculine Domination, Stanford: Stanford University Press 2001; G. Mosse, The Image of Man: The Creation of Modern Masculinity, Oxford: Oxford University Press 1996; S. Dudink, K. Hagemann and A. Clark (eds.), Representing Masculinity: Male Citizenship in Modern Western Culture, New York: Palgrave MacMillan 2007. 
the construction of masculinity in relation to femininity 'in a kind of fear of the female, firstly in oneself', ${ }^{35}$ Connell has highlighted the differences among men. He observed that in the late 19th century 'from the point of view of hegemonic masculinity, the potential for homosexual desire was expelled from the masculine and located in a deviant group, symbolically assimilated to women or to beasts ... heterosexuality became a required part of manliness. ${ }^{36}$ Crucial to the construction of a hegemonic masculinity is thus a clear separation from women and from the so-called feminine traits within oneself. This, however, stands in contrast to the way Jesus is often presented as an androgynous person. The literal understanding of androgyny as showing feminine as well as masculine physical features has often specific connotations. In Greek and Roman antiquity, the term androgyny was 'considered shameful and ... associated with the names of those in society who refused to play the traditional role of a man and a woman. ${ }^{37}$ Androgynous behaviour was understood 'in the case of a man, in playing a feminine role in social life generally and in sexual relationship in particular. ${ }^{38}$ There is a long cultural history of associating male androgyny with being a social outsider, and weak, passive and homosexual.

\section{Visual Images of Jesus}

David Morgan's observation that Christ's masculinity in popular religious images has been perceived differently according to their social and historical contexts, is central to my analysis. He noticed that there is an ambivalence in the popular religious images produced in the nineteenth century that depict Jesus as 'mother and father, male and female, friend and lover, even heterosexual and homoerotic. ${ }^{39}$ This is due to the fact that the boundaries between friendship, erotic love and charity were not as fixed and constant as they are now. It exemplifies how the perception of images changed in the course of time due to their cultural and social contexts. However, there are also different interpretations of the images within the same period of time and within the same social context, but dependent on the perspective of the individual.

Of special interest is that certain religious images became either popular or taboo due to shifting gender relations in society. An example is

35 Bourdieu, Masculine Domination, 53.

${ }^{36}$ Connell, Masculinities, 196.

37 L. Brisson, Sexual Ambivalence: Androgyny and Hermaphroditism in Graeco-Roman Antiquity, Berkeley: University of California Press 2002, 7-8.

38 Ibid., 66.

39 Morgan, Visual Piety, 101. 
given by Anne-Marie Korte who examined why representations of female crucified religious saints (dis)appeared at certain times, and how they were specifically employed by their creators to make a statement on societal gender relations. ${ }^{40}$

Tim Pursell, in his study of homoeroticism in Nazi art, argued for an openness to 'a host of readings' of images that also allows for finding 'queer moments' in supposedly heterosexual art. ${ }^{41}$ These are readings of images that were not intended originally by the artist. Pursell rightly states that the 'miss-understanding' of the images is often more interesting than the creator's intention. This is especially true with regard to the Sacred Heart representations, as they were not created as queer art.

However, a significant difference with Pursell's study is that the Sacred Heart images are not necessarily perceived as homoerotic by (Christian) gay men themselves. Rather queer Christians have started to create their own images. ${ }^{42}$ The gender transgression of Jesus plays an important role in this, as LGBTs are faced with the issue of the gender and sexuality of the divine. ${ }^{43}$ The resulting androgynous images of Jesus seem to specifically hit the nerve of fundamentalists who defend strict gender roles and feel threatened by the postmodern condition.

The notion of homoeroticism that emerges in the interpretation of the Sacred Heart images, and especially their cyberreligious parodies, also seems to be connected to their possible perception as 'camp'. The reason for this is that, as Bergman claims, there are a few characteristics of camp as a specific aesthetic style that most people can agree on, even if they remain contested. One of these characteristics is that 'camp is affiliated with homosexual culture, at least with a self-conscious eroticism that throws into question the naturalization of desire. ${ }^{44}$ While the satiric websites are made by secular critics of religion whose sexual identity remains unknown, rather than by LGBTs as producers of queer art, they conform to other traits of camp because they play with the alleged homoeroticism of the images. These are a preference for exaggeration and artifice as well as an ambivalent relationship with popular and consumerist

40 Korte, 'Madonna's kruisigingsscène'.

41 T. Pursell, 'Queer Eyes and Wagnerian Guys: Homoeroticism in the Art of the Third Reich', Journal of the History of Sexuality 17:1 (2008), 110 -137.

42 E. Heartney, Postmodern Heretics: The Catholic Imagination in Contemporary Art, New York: Midmarch Arts Press 2004.

43 Ibid., 146.

44 D. Bergman, Camp Grounds, Style and Homosexuality, Amherst: University of Massachusetts 1993, 5. 
culture. ${ }^{45}$ I agree with Patricia Bieszk who argued that the 'co-optation of camp by the mainstream', for which the satirical websites are exemplary, 'does not necessarily deprive camp of its "radical/progressive/liberal" potential. $^{46}$

Furthermore, I would like to take a look at the art history of images depicting Christ. David Freedberg observed that 'we fear the body in the image' as it reminds us of those aspects of our own sexuality that it may threaten or reveal. ${ }^{47} \mathrm{He}$ noticed that the 'desire to gaze on the representation is the desire to gaze on the object' and that the gaze itself fetishizes the object. This is especially relevant in the context of repressed homosexuality and homophobia amongst fundamentalist Christians.

The visual representation of Jesus has posed various challenges for artists right from the beginning. First of all, they had to resolve the issue that an icon of Christ is a paradox in itself being an image of a person who lived, was killed but has not died and who is at the same time human and divine. ${ }^{48}$ In addition, Jesus had to be set apart from a group of other (divine) figures. The early Church fathers saw one solution in depicting Christ as ugly, in order to set him apart from the beautiful Roman gods. ${ }^{49}$ Another challenge was to distinguish Jesus from the pagan philosophers and wonder healers in early Christianity. That resulted in representations that combined different elements, so Jesus was often depicted with the beard of the philosophers and the shoulder-length hair of the wonder healers, while his clothing and grooming were carefully underlined to differentiate him from the 'dirty' cynic wandering philosophers. ${ }^{50}$ These kinds of representations became a sort of a model for later representations, including the ones under discussion here. So, for a Western audience, Jesus, if he does not show the wounds of the crucifixion and/or a halo, is now recognizable by the following signifiers: a white dress-like robe, shoulder-length hair, full beard and sandals.

45 Ibid.

${ }^{46}$ P. Bieszk, 'Camp Lite or Camp Bite? Camp as a Post-Subcultural Sensibility in The Stepford Wives', Traffic 8 (2006).

47 D. Freedberg, The Power of Images: Studies in the History and Theory of Response, Chicago: The University of Chicago Press 1989, 12.

${ }^{48} \mathrm{H}$. Belting, 'In Search of Christ's Body: Image or Imprint?', in H. Kessler and G. Wolf (eds.), The Holy Face and the Paradox of Representation, Bologna: Nuova Alfa Editoriale 1998, 1-2.

49 Freedberg, The Power of Images, 211.

50 P. Zanker, Die Maske des Socrates: Das Bild der Intellektuellen in der Antiken Kunst, München: C.H. Beck Verlag 1995, 281-284. 
Another line of depiction in early Christianity was the portrayal of Christ as both feminine and masculine by presenting him with long hair and sometimes with breasts. ${ }^{51}$ This portrayal of Jesus served several purposes. First of all, the long hair was meant to set him apart from the apostles, who were usually depicted with short hair. Secondly, the reconciliation of the sexes, as embodied in an androgynous body, was understood as a symbol of salvation. This was based on the tradition of male Roman gods, who were often shown to be androgynous to underline their life-giving fecundity and on the theological understanding of Adam as androgynous. ${ }^{52}$ Finally, the feminine signifiers were designed to convey the womanly compassion of Jesus and to portray him as the nurturer of souls. ${ }^{53}$ In the following I will take a closer look at the potential androgyny of the Sacred Heart image.

\section{The Image of the Sacred Heart of Jesus}

The different versions of the Sacred Heart of Jesus are based on mystical visions of the seventeenth-century French nun Mary Margaret Alacoque. The message of the visions was centred on penance, obedience and patience as well as self-renunciation. Busch claims that this rhetoric and the central heart symbol suited the newly developed gender profiles in Germany well. The feminization of the devotion could only be explained in the context of secularization, industrialization and embourgeoisement in the nineteenth century. ${ }^{54}$ Broadly said, these processes had ascribed to men an active, rational public role and to women a passive, emotional private one. Ultramontane groups like the Jesuits saw this role distribution as divine will. These groups also supported Marian devotions and the devotion to the Sacred Heart of Jesus. The Sacred Heart image then came to symbolize ideal feminine qualities like patience and self-renunciation.

In the course of time different representations of the Sacred Heart were created. Here I focus on the most popular version on the Internet and in religious souvenir shops. The image shows the upper body of Christ who wears a white garment and looks right into the face of the viewer. His right hand is held up in a gesture of blessing. The left hand bearing a visible

51 T.F. Mathews, The Clash of the Gods: A Reinterpretation of Early Christian Art, Princeton: Princeton University Press 1993, 119.

52 Mathews, The Clash of the Gods, 138.

53 Ibid., 137.

${ }^{54}$ N. Busch, Katholische Frömmigkeit und Moderne: Die Sozial- und Mentalitätsgeschichte des Herz-Jesu-Kultes in Deutschland zwischen Kulturkampf und Erstem Weltkrieg, Gütersloh: Gütersloher Verlagshaus 1997, 272. 
wound points to his heart which is placed on his garment right in the middle of the chest. The heart wound is highly abstracted: it has a red, flaming heart-shaped form. It is surrounded by a crown of thorns and on top a cross is placed in the middle of yellow flames. Jesus' head as well as his heart are surrounded by a glowing halo.

Morgan observed that this version of the Sacred Heart image was explicitly designed to show Jesus as tender and androgynous, so believers would be enabled to develop an intimate relationship with him. ${ }^{55}$ This feminization of Jesus' representation ran parallel with the 'gentilizing and whitening' of Christ, so that most representations of Christ since then have shown him with white skin, blond hair and blue eyes. ${ }^{56}$ Anthony Easthope describes the 'disconcertingly feminine features', the signifiers of androgyny, as follows:

The dark brown hair is long and wavy, parted in the middle and curling at the ends ... the skin perfectly smooth... it is a straight little nose and a small pursed mouth; moustache and beard are as soft, fine and muted masculine as they could be ... the eyes, the main feature, are enormous, huge almond eyes with a touch of mascara, long sweeping lashes, thin penciled eyebrows ... since the head is slightly bent forward and to its right, the look comes to us from under the lids, and that is a look much more often associated with pictures and photographs of women. ${ }^{57}$

The representation contains a range of connotations and therefore displays an inherent ambivalence, as Jesus, the sign, can be read as either heterosexual or homoerotic, depending on the viewpoint of the onlooker. A heterosexual woman may be attracted (sexually) by his 'soft' manliness just as a gay man might be. At the same time his image can be read as that of an understanding friend or even a caring parent by both sexes, without any sexual connotations.

Morgan, Visual Piety, 23.

56 Richard Dyer, White, New York: Routledge 1997, 68.

57 A. Easthope, What a Man's Gotta Do: The Masculine Myth in Popular Culture, New York: Routledge 1990, 24-25. 


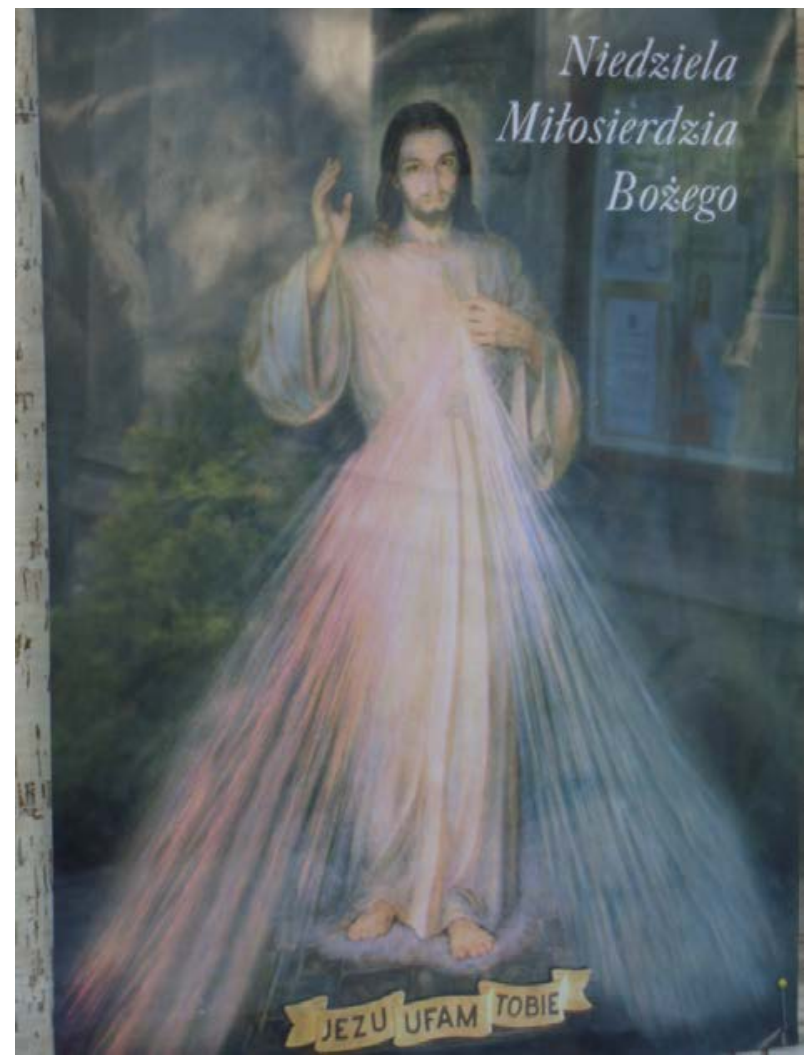

Poster in the front of a little church in Częstochowa showing the Merciful Jesus in the Hyla version (photo: Samson, 2009).

This version of the Sacred Heart image is also used for the most popular version of the image of Divine Mercy, which is among the most widespread contemporary devotions. In the case of the Divine Mercy picture we know who the painter is, while the creator of the Sacred Heart picture remains unknown. As the face and the upper body of this Divine Mercy Jesus are identical to the Sacred Heart version, it could be assumed that its creator, Adolf Hyla, copied this when he painted it in 1942. However, it is also possible that the later Divine Mercy image became so popular that someone applied it to the Sacred Heart version.

The Divine Mercy image always shows the full-length figure of Jesus and is accompanied by the words 'Jesus, I trust in You' at the bottom of the image. The burning heart radiates white or blue and red beams. These beams represent both God's mercy and the blood and water flowing from the wounds of the crucified Jesus. Parallelling the contours of his dress, they almost look as if they are part of it. In that way a certain resemblance to some Marian images is evoked, especially those in which beams of mercy are flowing from her hands. 
The Divine Mercy image is based on visions of a nun, the Polish saint Faustina Kowalska who was a Sister of Our Lady of Mercy. She was ordered to spread the devotion centring on penance, through the image in visions she received in 1931. The Sisters gave the painter Eugeniusz Kaszimirowski the assignment for a painting according to the visions, which he delivered in 1934. In 1941, the sisters received another version by Hyla in gratitude for the sisters' support of his family. However, the Hyla version, which the sisters placed above the tomb of Faustina, was strongly opposed by Faustina's spiritual leader, Father Michael Sopocko, as showing a too feminine Jesus. ${ }^{58}$

\section{Satiric Websites as Postmodern Interventions}

As daily life for the majority of Americans and Europeans has become influenced by the Internet, so has religion. Religious groups and individuals make use of it to communicate with their members, reach a wider audience and to convey religious experiences. ${ }^{59}$ Others employ it to voice their criticism of religion, especially the fundamentalist forms. Irony is an important element of these postmodern sites and manipulation or interpretation of popular religious images is a well-liked tool to bring out this criticism in a provocative and at the same time entertaining way. The sites employ means that used to be connected with camp as a playful aesthetics that 'turns values upside down' ${ }^{60}$ As postmodernism supports the view of an individual fluid identity, the supposed gender transgression of Jesus is a useful feature for these sites. Techniques for image manipulation, now easily accessible, and the Internet as a means of easy dissemination of these images, lend themselves perfectly to the widespread distribution of this new form of camp.

The larger websites on religion often provide a shop in which you can buy various items going with the parodies. Here a contested characteristic of camp comes to the fore: its ambivalent relationship with

58 www.divinemercysundayusa.com/onetrue.shtml;

www.mercyimages.com/history divine mercy image.aspx, accessed 23 December 2010.

59 P. Apolito, The Internet and the Madonna: Religious Visionary Experience on the Web, Chicago: Chicago University Press 2005; M. Altena, C. Notermans and T. Widlock, 'Tradition, Place and Community in Internet Rituals' in R. Grimes, U. Hüsken and E. Venbrux (eds.), Ritual, Media and Conflict, Oxford: Oxford University Press 2011, 133163.

60 D. Bergman, Camp Grounds: Style and Homosexuality, Amherst: University of Massachusetts Press 1993, 4. 
popular and consumerist culture. On the one hand, these ironic items and their strong promotion can be seen as criticism of consumerist culture, especially among Christians who are supposed to not care about material things. Nevertheless, they engage in consumerism themselves as the shops on the websites are real and the website makers often make a living out of the products being sold. ${ }^{61}$

With millions of visits each month and 1,400 webpages linked to it, the Landover Baptist Church is one of the most popular American satirical religious websites using the artworks by Hyla described above. Ownership and authorship of the site are claimed by Chris Harper who functions as the fictive alter ego Pastor Deacon Fred Smith on the website and in public appearances. ${ }^{62}$ Harper studied at Jerry Falwell's Liberty University until 1989 when he was expelled for producing a satirical radio show. ${ }^{63}$ Falwell was a highly public, and rather contested, figure of fundamentalist baptism and the founder of the Thomas Road Baptist (mega)church. Liberty University is attended today by about 12,000 students on campus. 61,000 students take classes online. ${ }^{64}$ In 1979, Falwell organized the Moral Majority, a political lobbying group that was pro-life, pro-family and in favour of a strong national defence. ${ }^{65}$ Falwell was also known for his strong stance against homosexuality. In 1977, he supported Anita Bryant's Save Our Children-campaign to counter a Florida ordinance promoting antidiscrimination policies for LGBTs. He even saw AIDS as a punishment for homosexuality by God and interpreted the terrorist attacks of September 11 th to be God's reaction to the public acceptance of homosexuality. ${ }^{66}$ While he later renounced some of these statements, and in 1999 even organized an anti-violence meeting between two hundred people of this church and two hundred gay civil rights activists, ${ }^{67}$ he nevertheless left a

${ }^{61}$ M.T. Hojsgaard, 'Cyber-Religion: On the Cutting Edge Between the Virtual and the Real', in M.T. Hojsgaard and M. Warburg (eds.), Religion and Cyberspace, Oxon: Routledge 2005, 56.

62 http://nobeliefs.com/GAMOW/GAMOW37.htm, last accessed 20 July 2011.

63 http://en.wikipedia.org/wiki/Landover Baptist_Church,

http://jmm.aaa.net.au/articles/17318.htm; last accessed 20 July 2011; unfortunately, no possibilities were found to contact Chris Harper directly and an e-mail written to the contact address of the Landover website itself remained unanswered.

64 http://www.liberty.edu/aboutliberty/index.cfm?PID=6921, accessed 6 September 2012.

65 http://www.liberty.edu/aboutliberty/index.cfm?PID=6921, accessed 6 September 2012.

66 http://www.milforddailynews.com/opinion/x1987843539, accessed 6 September 2012.

67 http://www.nytimes.com/1999/11/06/opinion/iournal-has-jerry-falwell-seen-thelight.html?pagewanted=2\&src=pm, accessed 6 September 2012. 
legacy of presenting a fundamentalist type of evangelicalism known for its close link of republican politics with religion and a strident homophobia. Because Harper was one of his students and this type of fundamentalism is still present in American society and politics, evangelical fundamentalism has become the main target of the satiric website.

The Landover website is 'in layout and design ... very spiffy and professional with good integration of images', ${ }^{68}$ so that some people have indeed mistaken it for an authentic site and sent in serious contributions to the webpage's blog. Due to some people's complaints about this, the site was taken from the AOL server in January 1998. However, it is still available via other Internet servers and therefore easily accessible. That despite the heavy irony the site actually can be mistaken for a serious website speaks to Harper's intention:

We [a group of writers from across the country; most of them experts on the fundamentalist movement] have devoted a good portion of our lives to studying Baptists. We know their beliefs, habits, their likes and dislikes. We believe that although Landover Baptist is a satire, it represents an accurate picture of what the Church is becoming. ${ }^{69}$

The Landover Baptist Church, which engages widely in commercialism, is divided into various ministries like BASH (Baptists Are Saving Homosexuals) and BITCH (Bringing Integrity To Christian Homemakers). There is an extensive online shop selling religious paraphernalia. These objects are often decorated with collages of the described iconic Jesus images.

The Hyla image, for example, has been manipulated in various ways to hint at its allegedly homoerotic potential and at the homophobia of fundamentalist Christians. It is not by accident that the resulting images are reminiscent of camp, an aesthetic that is associated as much with irony and artifice as with 'homosexual culture'. ${ }^{70}$ Even without manipulation the Hyla image as representation of an androgynous Jesus can be perceived as camp since 'the androgyne is certainly one of the great images of Camp sensibility. ${ }^{, 71}$ Therefore the parodies simply inflate the androgyny that is already present in the images.

On a poster advertising the fictitious movie THE PAYBACK OF THE CHRIST. THE CHRIST IS BACK \& HE IS PISSED OFF, the figure of Jesus stands centrally in front of a fiery apocalyptic background with the Statue of Liberty holding

${ }^{68}$ G.L. Dillon, Writing with Images: Towards a Semiotics of the Web, Washington: University of Washington Press 2002.

69 http://imm.aaa.net.au/articles/17318.htm, accessed 20 July 2011.

70 Bergman, Camp Grounds, 5.

71 S. Sontag, Against Interpretation, New York: Dell 1979, 279. 
the Bible. While the face has been only slightly altered by raising the eyebrows, the rest of the body has been completely changed. The fragile head was placed on the body of a heavily muscled fighter carrying a machine gun, signifier of hypermasculinity. The white and red tunic and the sandals still clearly identify the figure as Jesus. The collage of the effeminate and hypermuscular elements has a double effect: firstly, the contrast between the muscled body and the delicate face points out the fragility of the androgynous original depiction of Jesus and, secondly, the use of a hypermuscular body hints at another type of gay iconography, namely the celebration of the male body in its fullest potential with completely articulated muscles. ${ }^{72}$ That this is a criticism of fundamentalist Christianity is supported by the accompanying text which states that this movie is a sequel to Mel Gibson's THE PASSION OF CHRIST, which has received heavy criticism for its fundamentalist Christian message.

Various items saying 'As God is my waitress' allude to the alleged effeminacy by showing Jesus in a white waitress costume wearing a bonnet, signifier of femininity, and carrying a tray with an ice cup. Finally, there are stickers for sale with the head of the Hyla image, altered with raised eyebrows, saying 'Flatter me [Jesus] or I'll torture you in hell.' This can be understood as a reference to the supposed vanity of effeminate gay men, echoing the stereotype of female vanity.

It is easy to read all these depictions as criticisms of the suppressed homosexuality and homophobia of fundamentalist Christians. The mocking of homophobia and the explicit commercialism are both characteristic for the way that cyberreligious sites criticize and oppose established religions by pointing at their (supposed) hypocrisy. ${ }^{73}$ This link is made even more explicit in the category '4Kidsonly', in which a fictive kid asks why Jesus is shown in the Children's Bible with long hair like a homosexual. The answer is that most of these pictures 'were drawn by hell-bound, pasta-slurping, Mary-worshipping, hell-bound Catholics. ${ }^{174}$

Another criticism applies to the ex-gay movement, which is a 'network of religious, scientific and political organizations ${ }^{\prime 7}$ that claims

72 I. Ang, 'Mannen op zicht' in Tijdschrift voor vrouwenstudies 4:3 (1983), 433; C. van Rooy, 'In adamskostuum', Tijdschrift voor vrouwenstudies 8:4 (1987), 444; A. Ellenzweig, The Homoerotic Photograph: Male Images From Durieu/Delacroix to Maplethorpe, New York: Columbia University Press 1992.

${ }^{73}$ Hojsgaard, Cyber-Religion, 54.

74 http://www.landoverbaptist.org/news0205/jesushair.html, accessed 2 September 2012.

75 C. Robinson and S. Spivey, 'The Politics of Masculinity and the Ex-Gay Movement' in Gender and Society 21 (2007), 650. 
that homosexuality is a condition that can be healed through therapy and marriage. The LGBT movement has found the rejection of this claim crucial, because its acceptance would have abolished the grounds to grant LGBTs any specific rights. ${ }^{76}$ Pastor Lee refers to this claim especially by pointing out that 'there is a wife and five kids!' The ex-gay movement has developed various strategies, one of them is the establishment of camps where LGBT youth is claimed to be healed in group therapy. These camps have become the focus of parody in various strands of American popular culture. The popular TV cartoon series South Park, which is known for its biting social and political satire, on 14 March 2007 aired an episode called 'Cartman Sucks' that pointed out the frequent incidence of suicides among young LGBTs because of the feelings of guilt and shame induced in them by those camps. Thus, the Landover Parody finds its place as yet another variant in the well-established criticism of ex-gay therapies in American popular culture.

Christian fundamentalists have reacted to, on the one hand, the allegations of homophobia and their right-wing connections and, on the other hand, the growing legal protection of sexual minorities by applying various strategies. Several books have been written in which they claim that it is the sexual minority rights supporters who are endangering democracy by restricting the freedom of speech with anti-discrimination policies and hate speech laws and displaying a so-called Christianophobia. ${ }^{77}$ Another strategy seems to be that many of these Christian groups have replaced the androgynous depictions of Jesus with more 'manly' versions. In doing so Christian fundamentalists' strategies resemble those of the social movement to masculinize the Sacred Heart Movement in Belgium in the 19th century. Van Osselaer observed that various strategies were applied to achieve this goal: the devotion was given a stronger social impact, dominant symbols and semantics of nationalism were imitated and a new image of Jesus was promoted. ${ }^{78}$ However, different from our case, the image itself was not adapted but replaced by another one, namely

76 T. Fetner, 'Ex-Gay Rhetoric and the Politics of Sexuality', Journal of Homosexuality 50: 1 (2005), 84.

77 S. Hunt, "Human Rights and Moral Wrongs: The Christian "Gay Debate" in the Secular Sphere', in S. Hunt (ed.), Contemporary Christianity and LGBT Sexualities, Farnham: Ashgate 2009, 114; Fetner, Ex-Gay, 82; J. Samson, W. Jansen and C. Notermans, "The Gender Agenda": New Strategies in Catholic Fundamentalist Framing of NonHeterosexuality in Europe', Journal of Religion in Europe 4 (2011), 273-299.

78 T. van Osselear, 'De 'masculinisering' van de Heilige Hartdevotie in België?', Tijdschrift voor Genderstudies 11:3 (2008), 33-45. 
Jesus as King of Eternal Love with a crown and a sceptre. ${ }^{79}$ This was done not only to attract more men to the devotion, but also to counter the possibilities for erotic sublimation that the image offered for women and that were also recognized by men.

\section{(Re-)masculinizing the Sacred Heart and Divine Mercy Images}

One of the groups which attempt to promote an allegedly manlier image of Jesus is the Polish Radio Maryja. It activates the largest pilgrims group to the Black Madonna of Częstochowa with about 5,000 pilgrims a year. Radio Maryja is a nationalist Catholic fundamentalist media empire which is led by Father Tadeusz Rydzyk. It distributes its message not only via a national radio station, but also through the newspaper Nasze Dziennik (Our Daily) and the private television station TRWAM (I stay). ${ }^{80}$ It even has its own high school for political, cultural and media studies. The radio station is highly contested in Poland as well as in other countries and has received repeated criticism from the Vatican for interfering with politics. ${ }^{81}$ Father Rydzyk also asked for funds from the European Union to build this media high school?, but Premier Ronald Tusk denied Radio Maryja the money in 2008. The request for EU funds came as a surprise to many, as Radio Maryja has opposed the accession to Europe because it promotes moral relativism with regard to euthanasia, abortion and homosexuality.

79 N. Busch, Katholische Frömmigkeit und Moderne: Die Sozial- und Mentalitätsgeschichte des Herz-Jesu-Kulte in Deutschland zwischen Kulturkampf und Erstem Weltkrieg. Gütersloh: Gütersloher Verlagshaus 1997, 303.

I. Borowik, 'The Roman Catholic Church in the Progress of Democratic Transformation: The Case of Poland', Social Compass 49:2 (2002), 239-252.

81 P. Jenkins, God's Continent: Christianity, Islam and Europe's Religious Crisis, Oxford: Oxford University Press 2007, 67. 


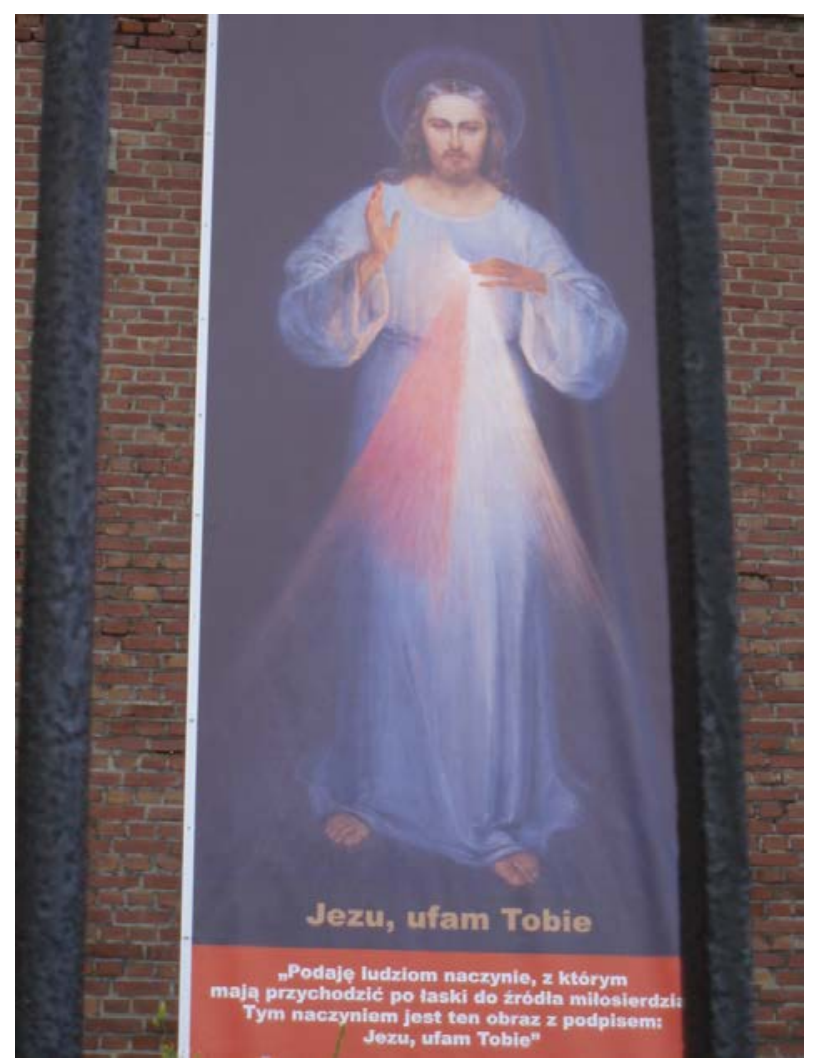

Flag with the Kazimirowski version of the Divine Mercy image hung over the sanctuary's wall during the pilgrimage of Radio Maryja in 2009 (photo: Samson, 2009).

Radio Maryja is also a supporter of the Divine Mercy devotion and hangs a large flag with the Divine Mercy image on the wall of the monastery immediately below the outside altar during their pilgrimages. In 2009, this image was the older Kaszimirowski version. As already mentioned, this version was promoted by Father Sopocko as the manlier, more appropriate version because of the following signifiers: his head is not tilted, but, instead, Jesus looks the viewer straight in the eye; the long hair almost vanishes in the dark background; the beams radiating from the heart are much shorter so that they remain largely within the confines of the robe and bear hardly any resemblance to Marian images; the wound of the heart is a fiery ball of light; the beard is more pronounced, so that it also covers the throat; his feet are wider apart and the body is more erect; the fingers are shorter, the eyes are smaller and he appears to be slightly tanned. 
I would like to suggest that the use of this particular rediscovered image by Radio Maryja can be read as yet another way of expressing rejection of the liberal paradigm of the EU. Of course, other interpretations such as nationalist re-affirmation of masculine Polish identity in the face of a powerful EU or the wish to offer a 'manly' alternative to the feminized space of the Marian pilgrimage site that is dominated by Marian images might be possible as well. The image may well serve several purposes at once. However, the following observation supports the first view. Parallel to the 'new' image I noticed that there was no direct address of the issue of homosexuality in the speeches of different speakers during the pilgrimage. Instead, a book, titled Europa bez Chrystuza? [Europe without Christ?] was heavily promoted. ${ }^{82}$ This work, by the Warsaw-based German journalist, Stefan Meetschen, claims that different societal groups, like liberals, supporters of the 'Gender Movement' and the 'Homo-Lobby', try to attack Christianity - an attack he regards as a new form of Christian persecution in Europe, and which he terms Christianophobia. It seems that Radio Maryja looked for different strategies to express its homophobia in order to avoid criticism. It refrained from any public utterances on the subject and simply pointed at a book that transports its message. An even more subtle way to promote hegemonic masculinity is the use of the Kaszimirowski version of the Divine Mercy image. Thus I would like to suggest that the image on the flag is employed here to convey cultural perceptions of masculinity on 'non-discursive levels of practical consciousness and unconsciousness.' 83

During the feast day of the Sacred Heart of Jesus on 20th June 2009, new versions of the Sacred Heart image were sold to the pilgrims at the site of the Black Madonna. The pilgrimage was organized by the archbrotherhood of the Guardians of the Sacred Heart of Jesus, a conservative spiritual lay organization connected to the Sisters of Visitation in Krakow. The image they promoted also differs from the popular, androgynous version by the following signifiers: the hair is not well-tended and blond but rather wild and dark brown, while the beard is also less groomed and more pronounced; the burning heart is a simple print on the creamcoloured robe in a faded red, and the robe looks more like a priest's garment than a dress; the hands are strong and show veins, the dark

${ }^{82}$ S. Meetschen, Europa bez Chrystuza?, Warszawa: Wydawnictow Sióstr Loretanek 2009.

83 I.M. Young, 'Abjection and Oppression: Dynamics of Unconscious Racism, Sexism and Homophobia', in A.B. Dallery, C.E. Scott with P.H. Roberts (eds.), Crises in Continental Philosophy, Albany: State University of New York Press 1990, 201. 
brown eyes are smaller and have no lashes; the head is not tilted, but he looks the viewer straight in the eyes.

Since no reasons are given by the groups themselves why they now prefer other versions of the Divine Mercy and the Sacred Heart of Jesus, the matter remains open to interpretation. It could be that the manlier versions also serve nationalist ideas of 'real men' defending the nation. As Stefan Dudink reminds us: 'One of the characteristic features of national crisis is that it might bring about drastic change in the socially acceptable ways of being a man. ${ }^{84}$ As these fundamentalists are often nationalistic, images of a muscular Christ have been used to support this nationalism, and nationalism is closely intertwined with the promotion of hegemonic masculinity, this seems to be a plausible argument. This is particularly true in the context of political discussions in Poland, which only recently won back its national autonomy and where many feel dominated by EU institutions.

However, it is also a fact that the Christian Churches, and especially the Catholic Church, have lost political influence in Europe and since then the 'Vatican's sexual conservatism has gained increasing prominence. ${ }^{85}$ Considering that 1 ) 'only the enormously powerful institution of organized Christianity could legitimate such an unusual picture [the popular version of the Sacred Heart], turn it into an image to be taken with seriousness and reverence, ${ }^{86}$ 2) the Church now loses power and 3) the fact that homosexuality is gaining more visibility, I would like to suggest that the fundamentalist groups consciously employ images that are less ambiguous with regard to Christ's sexuality in order to secure hegemonic masculinity. Furthermore, images can transport the concept of hegemonic masculinity in a subtle manner, whereas speeches or written texts are much more direct and thus more exposed to criticism.

\section{Conclusion}

I have shown that the contestation over Jesus' masculinity is ongoing and that the Sacred Heart and Divine Mercy images serve as powerful tools in the social struggle about hegemonic masculinity. It also became clear that what is perceived as signifier of hegemonic masculinity respectively marginalized masculinities is shifting according to societal, historical and

\footnotetext{
${ }^{84}$ S. Dudink, K. Hagemann and J. Tosh (eds.), Masculinities in Politics and War, Manchester: Manchester University Press 2004, 48.

85 Burns, 'Abandoning Suspicion', 73.

${ }^{86}$ Easthope, What a Man's Gotta Do, 25.
} 
political contexts. Therefore the images evoke quite divergent connotations and the need to adapt or invent new images arises. I have demonstrated that theological interpretations of images can clash with secular interpretations, especially with regard to Jesus' androgyny. That the androgynous signifiers of some representations of Jesus are not essential to identify him is proven by the new 'manlier' versions. Furthermore, the androgyny of Jesus is used here rather as a discursive tool by two opposing groups than as a theological concept.

With the rise of the Internet the play with and discussion of these images has been facilitated significantly, so that now religious websites compete with satirical websites over the interpretation of the images with respect to Christ's masculinity and homosexuality as a marginalized form of masculinity in general. There seems to be a contestation going on between religious fundamentalists and their critics over the issue of homosexuality via popular religious interpretations of Jesus. While a direct link between the American satirists and the Polish Catholic fundamentalists cannot be claimed, it is interesting to notice that both groups use the same images of Jesus for their respective ends. The satire makers mock the homophobia and the hypocrisy of fundamentalist Christians by manipulating the androgynous images in a postmodern way so as to suggest that they have a homoerotic potential. The own character of the images makes them especially suitable for entertainment and commercialism, more so than written or spoken texts.

Christian fundamentalists have started to reject the versions of these images that became the goal of parody and to replace them with supposedly manlier versions, either by creating new ones or by rediscovering older versions. In that way they attempt to reaffirm a hegemonic masculinity. In secular society, there is a growing approval of sexual minorities and therefore fundamentalist Christians might feel the need to reassert the primacy of heterosexuality (visually). In the case of Poland, the access to the EU and the need to adapt politically to its liberal paradigm have caused fundamentalist groups to explicitly reject homosexuality in order to affirm a Polish Catholic identity. The new images can be regarded as yet another way to express this rejection, but in a more subtle way now in reaction to the criticism of their public homophobic spoken messages.

The American satirists, on the other hand, have used the opposite strategy. They did not change the image of the Sacred Heart of Jesus with subtlety, but manipulated it in such a drastic way, that Jesus appeared as either totally feminized or hypermuscular. In that way they make a clear 
statement against the Catholic and Evangelist fundamentalist call for a hegemonic masculinity that is clearly heteronormative and relies on the stereotypical image of 'real hard men'. 